\title{
Effects of Cadmium Amendments on Low-Molecular-Weight Organic Acid Exudates in Rhizosphere Soils of Tobacco and Sunflower
}

\author{
Po-Neng Chiang, ${ }^{1}$ Ming Kuang Wang, ${ }^{1}$ Chih Yu Chiu, ${ }^{2}$ Shu-Yen Chou ${ }^{1}$ \\ ${ }^{1}$ Department of Agricultural Chemistry, National Taiwan University, Taipei, Taiwan, 106 \\ ${ }^{2}$ Biodiversity Center, Academia Sinica, Nan Kang, Taiwan, 115
}

Received 12 October 2005; revised 10 April 2006; accepted 16 May 2006

ABSTRACT: To recognize physiological response of plants to cadmium (Cd) toxicity in rhizosphere of
plants, the pot experiments were employed to investigate how low-molecular-weight organic acids
(LMWOAs) were exudated from tobacco and sunflower roots of Cd-amended soils. The aims of this study
were to assess the effect of LMWOAs on uptake of Cd by tobacco and sunflower under pot experiments,
thus comparing the ability of tobacco and sunflower for phytoremediation. Surface soils $(0-20 \mathrm{~cm})$ were
collected from Taichung Experiment Station (TC) (silty loam). Cadmium chloride $\left(\mathrm{CdCl}_{2}\right)$ was amended into
TC soil, giving Cd concentrations of $1,5,10 \mathrm{mg} \mathrm{kg}^{-1}$ soil. Soils with different concentrations of Cd were
put into $12 \mathrm{~cm}$ (i.d.) pots for incubation, and then 2 -week-old tobacco and sunflower seedlings were
transplanted into the pots. Tobacco and sunflower were grown in greenhouse for 50 days, respectively.
The rhizosphere and bulk soils, and fresh plant tissues were collected after harvest. The Cd concentra-
tions in the plant and transfer factor values in the sunflower were higher than that in the tobacco. No
LMWOAs were detected by gas chromatograph in bulk soils, and low amounts of LMWOAs were found in
uncontaminated rhizosphere soils. Acetic, lactic, glycolic, malic, maleic, and succinic acids were found in
the tobacco and sunflower rhizosphere soils. Concentrations of LMWOAs increased with increasing
amendment of Cd concentrations in tobacco and sunflower rhizosphere soils. Correlation coefficient $(r)$ of
concentrations of Cd amendment versus LMWOAs exudates of tobacco and sunflower were 0.85 and
0.98, respectively. These results suggest that the different levels of LMWOAs present in the rhizosphere
soil play an important role in the solubilization of Cd that bound with soil particle into soil solution and then
uptake by plants. 1006 Wiley Periodicals, Inc. Environ Toxicol $21: 479-488,2006$.

Keywords: gas chromatograph (GC); low-molecular-weight organic acids (LMWOAs); rhizosphere and bulk soils; sunflower; tobacco

\section{INTRODUCTION}

Cadmium (Cd) is a relative rare element and as such is usually present in the natural terrestrial environments at low

Correspondence to: M. K. Wang; e-mail: mkwang@ntu.edu.tw China.

Contract grant sponsor: National Science Council, Taiwan, Republic of

Contract grant numbers: 88-2313-B002-279, 89-2313-B002-279, 902213-B002-279.

Published online in Wiley InterScience (www.interscience.wiley.com). DOI 10.1002/tox.20210 concentrations. In the absence of contributions from anthropogenic activities, the base levels of the trace elements are controlled by the original lithology and weathering effects. Cadmium has been recognized to be a highly toxic element but it is only recently that more concern has been expressed about its possible effects on human health after the longterm exposure to low concentrations of the $\mathrm{Cd}$ element (Krishnamurti et al., 2005). Cadmium (Cd) in contaminated waters and soils is usually transferred into food chain and influence human and animal health. In general, $\mathrm{Cd}$ contents in soils ranged from 0.05 to $0.8 \mathrm{mg} \mathrm{kg}^{-1}$ soil (Kabata-Pendias

(C) 2006 Wiley Periodicals, Inc. 
and Pendias, 2000). Recently, biological methods for removing $\mathrm{Cd}$ have been used, particularly phytoremediation, to clean up environmental contaminations (Zhu and Shaw, 2000).

Plants have a remarkable ability to adsorb and accumulate metals and organic compounds from soil, water, and air. Recently, there has been an increasing interest in developing plant-based technology (phytoremediation) to remediate soils contaminated with heavy metals and radionuclides (Cunningham et al., 1995; Raskin et al., 1997; Raskin and Ensley, 2000). The hyperaccumulator plants gain tolerance to heavy metal ions through various detoxification mechanisms, which may include selective metal uptake, excretion, complexing by specific ligands, and compartmentation of metal-ligand complexes (Delhaize et al., 1993a,b; Rauser, 1999; Cobbet, 2000; Clemens, 2001). Saber et al. (1999) reported that detoxification mechanism of plant could be divided into two pathway: first, external tolerance through excretion of organic acids in the rhizosphere soil and, second, internal tolerance via chelation of heavy metal with organic acid in the cytoplasm, and transporting to vacuole. Phytoremediation techniques include phytoextraction, phytostabilization, phytovolatilization, phytodegradation, and phytofiltration (Salt et al., 1995; Chaney et al., 1997; Lombi et al., 1998; Wenzel et al., 1999; Garbisu and Alkorta, 2001). Phytoextraction accumulates toxic metals from contaminated soil into plant tissues, which are then harvested and buried after incineration (Kumar et al., 1995; Chaney et al., 1997; Wenzel et al., 1999; Garbisu and Alkorta, 2001).

Another option is the use of high biomass plants that are usually not considered to have metal-specific affinity and contain only low to average heavy metal concentrations, but which compensate for this by their high biomass, like tobacco (Keller et al., 2003). In contrast, some plants take up one or two specific metals and have a low biomass that is compensated by very high metal concentrations in the shoots (Baker and Brooks, 1989; Reeves and Baker, 2000). For example, sunflower can be used to remove toxic metals such as $\mathrm{Cu}^{2+}, \mathrm{Cd}^{2+}, \mathrm{Cr}^{6+}, \mathrm{Ni}^{2+}, \mathrm{Pb}^{2+}$, and $\mathrm{Zn}^{2+}$ from aqueous solutions (Dushenkov et al., 1995). Sunflowers have also been used to remove uranium and heavy metals from aqueous systems (Dushenkov et al., 1997). However, application and assessment of tobacco and sunflower to uptake $\mathrm{Cd}$ from contaminated soils are still in progress and the uptake mechanisms have not been well understood.

Soil-to-plant transfer of heavy metals is the major pathway of human exposure to soil contamination. Health risk due to soil contamination with single heavy metal has been widely studied. For example, lifetime exposure to low level soil contamination with cadmium $(\mathrm{Cd})$ has shown to cause renal dysfunction in residents living near the contamination sites in Japan (Ryan et al., 1982) and China (Cai et al., 1990; Nordberg et al., 1997; Watanabe et al., 1998, 2000; Jin et al., 2002). Recently, the transfer factor (TF) value was used to assess heavy metals and radionuclides transfer from soil to plant and phytoremediation was evaluated (Cui et al., 2004; Chiang et al., 2005; Guivarch et al., 1999). The TF values of plant species greater than 1.0 meant that the plant species could remediate contaminated soil.

Low-molecular-weight organic acids (LMWOAs) are natural products of root exudates, microbial secretions, and plant and animal residue decomposition in soils (Strom, 1997; Zhang et al., 1997; Cristofaro et al., 1998; Ebbs and Kochian, 1998). In recent studies, they have been implicated for altering the bioavailability and phytoremediation efficiencies of heavy metals in soils (Mench et al., 1988, 1994; Jones et al., 1996; Krishnamurti et al., 1997; Lee et al., 1997; Yang et al., 1997; Cieśliński et al., 1998; Onyatta and Huang, 2003). The metal chelation and/or complexing with LMWOAs for mobilization of mineral nutrients influence metal release from soils and inhibit the metal uptake by plants. Saber et al. (1999) investigated the role of organic acids in sunflower tolerance to $\mathrm{Al}^{3+}, \mathrm{Cd}^{2+}$, and $\mathrm{Zn}^{2+}$ and found that organic acids could detoxicate heavy metal tolerance. Huang et al. (1997) investigated the effect of organic acids amendment of uranium-contaminated soils and found that citric acid significantly increased metal availability and enhanced uranium accumulation many folds in the shoots of selected plants. Krishnamurti et al. (1997) reported that Cd was brought into soil solution from the soils by LMWOAs secreted by the plant roots. Although effects of several organic acids in heavy metal sorption and desorption from various clay minerals and oxides have been studied (Haas and Horowitz, 1986; Puls et al., 1991; Cristofaro et al., 1998), there is limited information on desorption behavior of heavy metals from natural soils by organic acids. The study assesses the LMWOAs exudation of tobacco and sunflower roots in Cd-contaminated soils, and compares the ability of tobacco and sunflower for phytoremediation.

\section{MATERIALS AND METHODS}

\section{Pot Experiments}

To recognize physiological response of plants to cadmium (Cd) toxicity in rhizosphere of plants, the pot experiments were employed to investigate how LMWOAs were exudated from tobacco and sunflower roots in $\mathrm{Cd}$-amended soils. Surface soils $(0-20 \mathrm{~cm})$ were collected from Taichung Experiment Station (TC) located at $120^{\circ} 32^{\prime} \mathrm{E}$ and $24^{\circ} 00^{\prime} \mathrm{N}$. Cadmium chloride $\left(\mathrm{CdCl}_{2}\right)$ was amended into $\mathrm{TC}$ soils, giving $\mathrm{Cd}$ concentrations of $1,5,10 \mathrm{mg} \mathrm{kg}^{-1}$ soil, and these soils with different concentrations of $\mathrm{Cd}$ were incubated in plastic pots $(15 \mathrm{~cm}$ in diameter and $16 \mathrm{~cm}$ in height) for 1 month. After incubation, 144, 190, and $567 \mathrm{mg}$ urea, superphosphate, and potassium chloride fertilizers, respectively, were added to each pot, and $\mathrm{N}, \mathrm{P}$, and $\mathrm{K}$ 
values remained at 60,30 , and $30 \mathrm{~kg} \mathrm{ha}^{-1}$, respectively. Soil moisture was maintained as $80 \%$ in water capacity, and weighted with water every day.

Seeds of tobacco and sunflower were germinated for 3 days on a Petri dish filled with water-soaked sponge. Seedlings were transported to pots and placed in a greenhouse. Six seedlings were planted per pot and were thinned to three seedlings per pot after 3 days. An extra pot without seeds was set at the same conditions as a control treatment. The greenhouse had $300 \mu \mathrm{mol}$ photons $\mathrm{m}^{-1} 2 \mathrm{~s}^{-1}$ at the top of the canopy, supplied by fluorescent/incandescent lamps with $12 \mathrm{~h}$ light period. Relative humidity was controlled to beyond $50 \%$ with a vaporizer, and temperature was maintained between 25 and $30^{\circ} \mathrm{C}$. Seedlings were watered every day.

Tobacco (Nicotiana benthamiana) and sunflower (Helianthus annuus) were grown in greenhouse for 50 days, respectively. After harvest, tissues were separated into shoots and roots. Shoots and roots were washed with distilled water, and then dried at $60^{\circ} \mathrm{C}$ for $72 \mathrm{~h}$. The rhizosphere and bulk soils were also collected on harvest. LMWOAs were exudated by plant roots of rhizosphere soils, which were identified by gas chromatograph (GC) (Szmigielska et al., 1997).

\section{Rhizosphere and Bulk Soils}

Taichung (TC) surface soil is classified as old slate alluvial soil, Eutrochrepts (Soil Survey Staff, 2003). The soils that remained adhered to the root after gentle shaking were sampled as rhizosphere soils by operating definition (Lynch, 1990; Chen et al., 2001). Root exudates appear primarily from fine roots near root tips, which are usually closely spaced in the root soils. The bulk soils were collected without planted soils. Fresh roots and leaves were also collected for comparison. The samples were collected immediately and preserved with dry ice. Soil and plant materials were ground and passed through a sieve $(<2 \mathrm{~mm})$, and then stored in a deep freezer at $-24^{\circ} \mathrm{C}$.

\section{Soil Analysis}

Soil samples were air dried and crushed by passing them through a $2 \mathrm{~mm}$ sieve. Soil $\mathrm{pH}$ was determined on 1:1 soil to water suspension using a $\mathrm{pH}$ meter. Soil texture was determined by pipette method (Gee and Bauder, 1986). Cation-exchange capacity was determined by $\mathrm{NH}_{4} \mathrm{OAc}$ method (Rhoades, 1982). Soil exchangeable cations were extracted by $1 \mathrm{M} \mathrm{NH}_{4} \mathrm{OAc}(\mathrm{pH}$ 7.0) solution. The extracted $\mathrm{K}, \mathrm{Na}$, $\mathrm{Ca}$, and $\mathrm{Mg}$ were determined by an atomic absorption spectrometer (AA, Hitachi, 180-30). Total carbon and nitrogen content were determined by flash combustion method (Fisons, NA 1500).

\section{Heavy Metal Contents in Plants and Soils}

Air-dried soils of about $0.5 \mathrm{~g}$ or ground shoots and roots of about $0.4 \mathrm{~g}$ were placed in a digested bottle, and $10 \mathrm{~mL}$ $70 \% \mathrm{HNO}_{3}$ solution was added and predigested under an exhausts hood for $20 \mathrm{~min}$. With the lids covered, the samples were placed in a microwave oven (Cem Co, Mars-5) for $10 \mathrm{~min}$ (Krishnamurti et al., 1994). After digestion, the samples were cooled and filtered with Whatman \#42 filter paper, and diluted to $25 \mathrm{~mL}$ in a volumetric flask. The $\mathrm{Cd}$, $\mathrm{Pb}, \mathrm{Cu}$, and $\mathrm{Zn}$ concentrations in soils, and $\mathrm{Cd}$ in plant tissues were determined by Induced Couple Plasma (ICP, Optima 2000 DV).

\section{Quantitative Evaluation of Sample Preparation for GC Analysis}

For GC analysis of nonvolatile LMWOAs, $1 \mathrm{~mL}$ of membrane effluent was extracted three times with $2 \mathrm{~mL}$ portions of ethyl acetate extraction. Each time, the upper ethyl acetate layer was withdrawn from a vial and transferred to a $2 \mathrm{~mL} \mathrm{~V}$-vial, heated and evaporated to dryness under a gentle stream of nitrogen. The LMWOAs analysis of this study was modified from the method of Szmigielska et al. (1997). One milliliter of membrane effluents were vacuum-dried in a Speed vac concentractor to avoid its loss during fractionation of ethyl acetate extraction layer. This was done to test the loss of nonvolatile vacuum-dried LMWOAs and ethyl acetate extraction- $\mathrm{N}_{2}$ of TMC derivatives (Szmigielska et al., 1997; Chen et al., 2001). Table II shows that the GC signal intensities of $20 \mathrm{mg} \mathrm{L}^{-1}$ standard acids of vacuumdried membrane effluents are greater than that of ethyl acetate extraction- $\mathrm{N}_{2}$ method, indicating a smaller LMWOAs loss when using the vacuum dry method. On the other hand, the determination coefficient $\left(r^{2}\right)$ of these five standard nonvolatile dicarboxylic acids by vacuum dry or ethyl acetate$\mathrm{N}_{2}$ method is 0.99 . Both methods showed significant correlation, indicating that the vacuum dry method can be replaced by ethyl acetate extraction- $\mathrm{N}_{2}$ method. Nonvolatile LMWOAs could not be detected in the pot experiments of controlled sample without seeds of tobacco and sunflower.

\section{Sample Stability and Recovery Test of LMWOAs Determinations by GC}

Derivated samples of LMWOAs were quite stable when stored under refrigeration and then transported to laboratory on dry ice (Krzyszowska et al., 1996). Rhizosphere soil samples analyzed after 1 month of storage in a refrigerator $\left(-24^{\circ} \mathrm{C}\right)$ showed no signs of decomposition (Chen et al., 2001). Recovery of the extraction/concentration and derivitization procedure was evaluated in fresh plants and 
rhizosphere soils of tobacco and sunflower. Soil samples $(15 \mathrm{~g})$ and plant tissues ( $1 \mathrm{~g})$ were analyzed to determine the initial organic acid concentration. Five milliliter of the standard mixture containing $10 \mathrm{~mL}$ of each acid and blank was added to $250 \mathrm{~mL}$ of centrifuge tubes, with $20 \mathrm{~mL} \mathrm{HCl} /$ $\mathrm{MeOH}(0.5 \mathrm{M})$ extraction. The tubes were shaken for $1 \mathrm{~h}$ and centrifuged at $10,000 \times g$. One milliliter of supernatant was subjected to GC analysis as described above. The standard curve has a high correlation coefficient $\left(r^{2}=0.99\right)$.

\section{Transfer Factor}

The assessment of cadmium contamination of the above standing vegetation has long been based on the determination of TF coefficient. The former expresses the ratio of cadmium concentration in two compartments (soil and plant), while the latter describes the transfer via a compete chain of parameters (e.g., from the soil surface to the plant).

$$
\mathrm{TF}=\frac{\text { concentration in plant }}{\text { concentration in soil }}\left[\frac{\mathrm{mg} \mathrm{kg}^{-1}}{\mathrm{mg} \mathrm{kg}^{-1}}\right]
$$

\section{Statistical Analysis}

The pot experiment was set up in randomized complete block design replicated three times. ANOVA (SAS version 10.0) was employed for statistical analysis of data. Statistical significance was defined as $P=0.05$.

\section{RESULTS AND DISCUSSION}

\section{Soil Physical and Chemical Properties}

Soil $\mathrm{pH}$, organic carbon, and total nitrogen of the TC soil are $6.3,24.3$, and $1.3 \mathrm{~g} \mathrm{~kg}^{-1}$ soil, respectively. Cationexchange capacity, exchangeable $\mathrm{Ca}, \mathrm{K}, \mathrm{Na}$, and $\mathrm{Mg}$ of $\mathrm{TC}$ soils are 9.0, 7.5, 0.2, 0.1, and $0.7 \mathrm{cmol} \mathrm{kg}^{-1}$ soil, respectively. Soil texture is silty loam. Only trace amounts of heavy metals $(\mathrm{Cd}, \mathrm{Pb}, \mathrm{Cu}$, and $\mathrm{Zn})$ were detected in the uncontaminated TC surface soils.

\section{Biomass and Distribution of Cd in Plant Tissues}

\section{Biomass}

Biomass growth of the two plants grown in soils for 50 days, including control and Cd-amended treatments, are summarized in Table I. The biomass of root and shoot of the tobacco and sunflower in the control treatment were significantly higher than that in the $\mathrm{Cd}$-amended treatment $(P<0.05)$. This indicates that high levels of $\mathrm{Cd}$ in the soil inhibited the growth of those two plants. The biomass of root and shoot in the tobacco was significantly decreased $(P<0.05)$ by adding 1,5 , or $10 \mathrm{mg} \mathrm{kg}^{-1}$ soil $\mathrm{Cd}$. However, the biomass of root and shoot of sunflower did not show
TABLE I. Dried weight of tobacco and sunflower after 50 days' growth in Cd-contaminated soils

\begin{tabular}{llll}
\hline & \multicolumn{3}{c}{ Dry Weight $\left(\mathrm{g} \mathrm{plant}^{-1}\right)$} \\
\cline { 2 - 4 } Treatment & Root & Shoot & Total \\
\hline Tobacco & & & \\
$\quad$ Control & $0.35 \mathrm{a}$ & $2.53 \mathrm{a}$ & 2.88 \\
$1 \mathrm{mg} \mathrm{Cd} \mathrm{kg}{ }^{-1}$ & $0.25 \mathrm{~b}$ & $2.30 \mathrm{a}$ & 2.55 \\
$5 \mathrm{mg} \mathrm{Cd} \mathrm{kg}$ & $0.13 \mathrm{c}$ & $1.93 \mathrm{~b}$ & 2.06 \\
$10 \mathrm{mg} \mathrm{Cd} \mathrm{kg}$ & $0.13 \mathrm{c}$ & $1.78 \mathrm{bc}$ & 1.91 \\
$\mathrm{LSD}_{0.05}$ & 0.10 & 0.50 & \\
Sunflower & & & \\
Control & $0.10 \mathrm{a}$ & $0.35 \mathrm{a}$ & 0.45 \\
$1 \mathrm{mg} \mathrm{Cd} \mathrm{kg}$ & $0.08 \mathrm{~b}$ & $0.23 \mathrm{~b}$ & 0.31 \\
$5 \mathrm{mg} \mathrm{Cd} \mathrm{kg}$ & $0.08 \mathrm{~b}$ & $0.22 \mathrm{~b}$ & 0.30 \\
$10 \mathrm{mg} \mathrm{Cd} \mathrm{kg}$ & $0.08 \mathrm{~b}$ & $0.21 \mathrm{~b}$ & 0.29 \\
LSD $_{0.05}$ & 0.02 & 0.10 & \\
\hline
\end{tabular}

The probability level of significant difference is at $P=0.05$. Replicates $(n)=3$.

significant difference among added Cd treatment. This suggested that sunflower could exist in contaminated soil, especially in high contaminated soil. The biomass of root and shoot in the tobacco were higher than that in sunflower among three levels of $\mathrm{Cd}$ amendment. This indicated that although tobacco contained higher biomass than sunflower, the biomass of tobacco was also affected by $\mathrm{Cd}$ concentration.

\section{Distribution of Cd in Plant Tissues}

Distributions of $\mathrm{Cd}$ in the two plant tissues are shown in Table II. Cadmium levels in the tobacco and sunflower roots are $50.0 \mathrm{mg} \mathrm{kg}^{-1} \mathrm{~d}_{\mathrm{w}} \mathrm{w}^{-1}$ and $179.0 \mathrm{mg} \mathrm{kg}^{-1} \mathrm{~d}_{\mathrm{w}}{ }^{-1}$, respectively. In both tobacco and sunflower, the Cd concentration of plant growing in the $\mathrm{Cd}$-amended soil was significantly higher $(P<0.05)$ than those growing in the control treatment. It is obvious that the higher concentration of $\mathrm{Cd}$ in a plant indicates the better ability of the plant to take up the $\mathrm{Cd}$. The $\mathrm{Cd}$ concentration in the sunflower roots and shoots was significantly higher by $2.1-4.1$ and $4.6-5.1$ times, respectively, $(P<0.05)$ than that in tobacco (Table II), indicating that the plant tissues of sunflower can uptake more $\mathrm{Cd}$ than those of tobacco. Concerning $\mathrm{Cd}$ distribution in plant tissues, the two species of plant accumulated higher concentration of $\mathrm{Cd}$ in roots than in their shoots, supporting the observation that the roots of plants can retain heavy metals (Xia and Shu, 2001; Xia, 2004). The shoot/root ratio of the sunflower decreased with increasing $\mathrm{Cd}$ concentration in the soil, but the shoot/root of the tobacco did not show this trend. Tobacco is a kind of high-biomass plant; it can take up all kind of metals. However, the sunflower is a kind of low-biomass plant and can take up specific metals, especially $\mathrm{Cd}$. Thus, the result 
TABLE II. The concentrations of $\mathrm{Cd}$ in the roots, shoots, and whole plant of tobacco and sunflower, harvesting at the 50th day after planting with the different concentrations of $\mathrm{Cs}$ treatments

\begin{tabular}{|c|c|c|c|c|}
\hline Treatment & $\operatorname{Root}\left(\mathrm{mg} \mathrm{kg}^{-1}\right)$ & Shoot $\left(\mathrm{mg} \mathrm{kg}^{-1}\right)$ & Total $\left(\mathrm{mg} \mathrm{kg}^{-1}\right)$ & Shoot/Root \\
\hline \multicolumn{5}{|l|}{ Tobacco } \\
\hline Control & $1.6 \mathrm{a}$ & $0.4 \mathrm{a}$ & $0.6 \mathrm{a}$ & 2.01 \\
\hline $1 \mathrm{mg} \mathrm{Cd} \mathrm{kg}^{-1}$ & $3.9 \mathrm{a}$ & $2.2 \mathrm{~b}$ & $2.3 \mathrm{a}$ & 5.19 \\
\hline $5 \mathrm{mg} \mathrm{Cd} \mathrm{kg}^{-1}$ & $39.0 \mathrm{~b}$ & $6.3 \mathrm{c}$ & $8.3 b$ & 2.40 \\
\hline $10 \mathrm{mg} \mathrm{Cd} \mathrm{kg}^{-1}$ & $50.0 \mathrm{c}$ & $11.0 \mathrm{~d}$ & $26.0 \mathrm{c}$ & 3.01 \\
\hline $\mathrm{LSD}_{0.05}$ & 7.4 & 1.5 & 3.2 & \\
\hline \multicolumn{5}{|l|}{ Sunflower } \\
\hline Control & $3.3 \mathrm{a}$ & $2.2 \mathrm{a}$ & $2.0 \mathrm{a}$ & 2.33 \\
\hline $1 \mathrm{mg} \mathrm{Cd} \mathrm{kg}^{-1}$ & $15.9 \mathrm{a}$ & $10.1 \mathrm{a}$ & $14.0 \mathrm{~b}$ & 1.83 \\
\hline $5 \mathrm{mg} \mathrm{Cd} \mathrm{kg}^{-1}$ & $93.2 \mathrm{~b}$ & $36.8 \mathrm{~b}$ & $40.0 \mathrm{c}$ & 1.09 \\
\hline $10 \mathrm{mg} \mathrm{Cd} \mathrm{kg}^{-1}$ & $179.0 \mathrm{c}$ & $53.2 \mathrm{c}$ & $70.0 \mathrm{~d}$ & 0.78 \\
\hline $\mathrm{LSD}_{0.05}$ & 16 & 7.8 & 10 & \\
\hline
\end{tabular}

The probability level of significant difference is at $P=0.05$. Replicates $(n)=3$.

suggests that the uptake and transferring of different plant species to the same metal are also different.

\section{Accumulation of $\mathbf{C d}$ in the Plants}

The accumulation amounts of $\mathrm{Cd}$ in these two plants showed a great disparity because of the different biomass and different Cd concentrations (Tables I and II). In the contaminated soils, the $\mathrm{Cd}$ accumulation in sunflower roots was higher than that in tobacco, whereas the $\mathrm{Cd}$ accumulation in shoot and total plant tissues of tobacco was higher than that in the sunflower. This suggests that the larger amount of $\mathrm{Cd}$ in the shoot and total plant tissues of tobacco was mainly due to the larger biomass. Although the biomass of sunflower shoot and total plant was less than that of the tobacco, the Cd concentration in the shoot of sunflower was higher than that of tobacco. The accumulation of $\mathrm{Cd}$ in the plant tissue is affected by two factors: biomass and Cd concentration in the plant tissue. When conducting phytoremediaction to remove metals from soil, the first considered factor is to select the species with high uptake ability, and then that with biomass. Furthermore, plants having high uptake ability can tolerate higher toxicity, and can be better cultivated in a highly contaminated area. Although the biomass of sunflower shoots did not increase with increasing Cd concentration, $\mathrm{Cd}$ accumulation in the sunflower indeed increased. Therefore, the $\mathrm{Cd}$ accumulation in the aboveground part increases if biomass increased.

\section{Transfer Factor}

The effectiveness of contaminant transfer from soils into plants was quantified by the TF $\left([\mathrm{Cd}]_{\text {root }} /[\mathrm{Cd}]_{\text {soil }}\right]$ or $\left.[\mathrm{Cd}]_{\text {shoot }} /[\mathrm{Cd}]_{\text {soil }}\right)$, which was the concentration of element of interest in the dried plant tissues divided by its concentration in the soils. The TF value is shown in Table III.
With application of 1,5 , and $10 \mathrm{mg} \mathrm{kg}^{-1}$ soil $\mathrm{Cd}$ in tobacco, the TF in roots are 3.9, 7.8, and 5.0 (Table III); while in shoots are $2.2,1.3$, and 1.1 , respectively. On the other hand, the TF values in sunflower roots are 15.9, 18.6, and 17.9, and in shoots are 10.1, 7.4, and 5.3. The TF values of $\mathrm{Cd}$ in the tobacco roots and shoots are lower than that of the sunflower. This indicates that the transfer ability of $\mathrm{Cd}$ in sunflower is better than that in tobacco, so the sunflower has high potential for phytoremediation. Heavy metal can be either stored in root or transported to shoot. While Cd is transferred to both root and shoot of sunflower in contaminated soil, it is transferred just to root in tobacco (Table III), indicating that $\mathrm{Cd}$ is more readily translocated through the vascular system of sunflower. It was recently shown that heavy metals hyperaccumulation and detoxification include chelation to organic acids (Lee et al., 1977; Stephan and Scholz, 1993; Oven et al., 2002) or protein (Martens et al., 1996). In the shoot, metallothioneins, phytochelatins, homophytochelatins, organic acids, and amino acids are involved in chelating and detoxification processes of heavy metals (Clemens, 2001). Thus, Cd could be transferred from soil to root and shoot of sunflower easily than that of tobacco in the contaminated soil. By comparing the TF values in roots and shoots, it was found that the TF values in roots are higher than those of shoots, indicating higher transfer $\mathrm{Cd}$ from soils into roots. Application of high

TABLE III. Transfer factor (TF) value of tobacco and sunflower

\begin{tabular}{lccccr}
\hline & \multicolumn{2}{c}{ Tobacco } & & \multicolumn{2}{c}{ Sunflower } \\
\cline { 2 - 3 } \cline { 6 - 6 } Treatment & Root & Shoot & & Root & Shoot \\
\hline $1 \mathrm{mg} \mathrm{Cd} \mathrm{kg}^{-1}$ & 3.9 & 2.2 & & 15.9 & 10.1 \\
$5 \mathrm{mg} \mathrm{Cd} \mathrm{kg}^{-1}$ & 7.8 & 1.3 & & 18.6 & 7.4 \\
$10 \mathrm{mg} \mathrm{Cd} \mathrm{kg}^{-1}$ & 5.0 & 1.1 & & 17.9 & 5.3 \\
\hline
\end{tabular}


Cd into soils caused low TF values in shoots, indicating the inhibition and toxicity of plant growth by high $\mathrm{Cd}$ amendment. Plants have been documented to increase TF value when stressed by harsh environments (Xia et al., 1999). In the present study, the root TF values of these two plants in the amended treatments decreased with increasing Cdamended concentration. This suggests that $\mathrm{Cd}$ in the soil inhibited growth of plants, especially their shoots. Although the TF value of sunflower shoot was decreased with increasing $\mathrm{Cd}$ concentration in the soil, the TF values were still higher than 1 . Thus, $\mathrm{Cd}$ could still be effectively absorbed and translocated to the above-ground part.

\section{Correlation Between LMWOAs from Plant Roots and Cd Contents in Plant Tissues}

The exudation amounts of LMWOAs by the two plants are shown in Table IV. Acetic, lactic, glycolic, maleic, and succinic acids were present in the tobacco and sunflower rhizosphere soils. Similar ranges in types of LMWOAs have been identified for other plant species (Stevenson, 1967; Kraffczyk et al., 1984; Baziramakenga et al., 1995; Cieśliński et al., 1998). No LMWOAs were detected by GC in bulk soils, indicating that the LMWOAs found in the rhizosphere were directly from root exudates and/or microbial metabolites at the soil/root surface. The maximum detection limit was $1 \mathrm{mg} \mathrm{L}^{-1}$. The total amounts of LMWOAs of the two plants in the soils of three treatments and one control treatment ranged from 1097 to $2614 \mu \mathrm{mol} \mathrm{kg}^{-1}$ soil, resembling closely the values for rhizosphere soil reported by Fox and Comerford (1990) for pine, Cieśliński et al. (1998) for durum wheat, and Baziramakenga et al. (1995) for quackgrass. Concentrations of LMWOAs increase with increasing amendment of $\mathrm{Cd}$ concentrations in tobacco and sunflower rhizosphere soils. The increase in LMWOAs release in the presence of $\mathrm{Cd}$ can be explained based on the complexation of the soil particulate-bound $\mathrm{Cd}$ with LMWOAs, which is reflected in the LMWOAs release from the two plants with the increase in the concentration of $\mathrm{Cd}$. The importance of the formation of metal-LMWOA complexes in increasing the solubility of trace elements in the soil rhizosphere was also suggested earlier (Merckx et al., 1986; Mench et al., 1988). Glycolic and maleic acids were dominant in tobacco rhizosphere soils. On the other hand, acetic, malic, maleic, and succinic acids were identified and dominated by acetic acids in the sunflower rhizosphere soils (Table IV). The citric acid was not determined in the rhizosphere soils of sunflower and tobacco. In this study, the LMWOAs were concentrated by anion exchange membrane from soil suspension. If the formation of metal-LMWOAs complex exists, the LMWOAs could not be exchanged to anion exchange membrane. The formation of metalLMWOAs complexes was depended on stability constants of metal ion complexes (Sillen and Martel, 1964). The $\mathrm{pK}$ values of stability constants of Cd-acetic, lactic, glycolic, maleic, succinic, and citric acids were 1.50, 1.70, 1.87, 2.40, 2.10, and 3.98, respectively (Sillen and Martel, 1964). The higher amounts of $\mathrm{Cd}$ ion in the soil could occur because of the formation of $\mathrm{Cd}$-citrate complexes or precipitations (i.e., stability constant of Cd-citrate, $\mathrm{pK}=3.98$ ) (Sillen and Martell, 1964), resulting in concentrations of citric acid below the minimum detection limit $(1.0 \mu \mathrm{mol}$ $\mathrm{kg}^{-1}$ ). Moreover, the calcium ion in the soil would be precipitated with organic acids, resulting in organic acids below the minimum detection limit (Cieśliński et al., 1998). The increase in LMWOAs exudates with increasing $\mathrm{Cd}$ amendments is based on the complexation of the soil particulate-bound Cd with LMWOAs, which is reflected in the LMWOAs exudateion from tobacco and sunflower with

TABLE IV. LMWOAs species and contents in rhizosphere soils of tobacco and sunflower treated with various $\mathrm{Cd}$ concentrations

\begin{tabular}{|c|c|c|c|c|c|c|c|}
\hline \multirow[b]{2}{*}{ Treatment } & Acetic Acid & Lactic Acid & Glycolic Acid & Malic Acid & Maleic Acid & Succinic Acid & Total \\
\hline & \multicolumn{7}{|c|}{$\mu \mathrm{mol} \mathrm{kg}^{-1}$} \\
\hline \multicolumn{8}{|l|}{ Tobacco } \\
\hline Control & $60 \mathrm{a}$ & $67 \mathrm{a}$ & $489 \mathrm{a}$ & ND & $384 a$ & $98 \mathrm{a}$ & $1097 \mathrm{a}$ \\
\hline $1 \mathrm{mg} \mathrm{Cd} \mathrm{kg}^{-1}$ & $114 \mathrm{~b}$ & $113 b$ & $595 \mathrm{a}$ & ND & $429 a$ & $115 \mathrm{a}$ & $1364 a$ \\
\hline $5 \mathrm{mg} \mathrm{Cd} \mathrm{kg}^{-1}$ & $146 b c$ & $145 c$ & $671 \mathrm{ab}$ & ND & $485 \mathrm{ab}$ & $132 \mathrm{ab}$ & $1579 a$ \\
\hline $10 \mathrm{mg} \mathrm{Cd} \mathrm{kg}{ }^{-1}$ & $261 c$ & $154 \mathrm{c}$ & $797 \mathrm{c}$ & ND & $504 b$ & $174 b$ & $1889 b$ \\
\hline $\mathrm{LSD}_{0.05}$ & 37 & 27 & 148 & & 104 & 30 & 345 \\
\hline \multicolumn{8}{|l|}{ Sunflower } \\
\hline Control & $829 a$ & ND & ND & ND & $184 a$ & $332 \mathrm{a}$ & $1345 a$ \\
\hline $1 \mathrm{mg} \mathrm{Cd} \mathrm{kg-1}$ & $1115 b$ & ND & ND & $140 \mathrm{a}$ & $453 b$ & $368 \mathrm{a}$ & $2075 b$ \\
\hline $5 \mathrm{mg} \mathrm{Cd} \mathrm{kg-1}$ & $1582 \mathrm{c}$ & ND & ND & $220 b$ & $461 b$ & $553 b$ & $2815 \mathrm{c}$ \\
\hline $10 \mathrm{mg} \mathrm{Cd} \mathrm{kg-1}$ & 2096d & ND & ND & $269 c$ & $555 \mathrm{c}$ & $694 c$ & $2614 d$ \\
\hline $\mathrm{LSD}_{0.05}$ & 347 & & & 45 & 102 & 122 & 601 \\
\hline
\end{tabular}

ND, Negative detection. 
increasing $\mathrm{Cd}$ concentrations. The importance of the formation of metal-LMWOA complexes with increasing the solubility of trace elements in the soil rhizosphere was also reported earlier (Merckx et al., 1986; Mench et al., 1988). The total amounts of LMWOAs in the rhizosphere soils of sunflower were higher than those of tobacco, indicating that the sunflower was more Cd-resistant than tobacco, and could exude more total organic acids to reduce $\mathrm{Cd}$ toxicity. The ability of plants to produce varying levels of organic acids has also been demonstrated for aluminum tolerant (Basu et al., 1994; Pellet et al., 1995; Ryan et al., 1995), cadmium detoxification (Cieśliński et al., 1998), chromium detoxification (Srivastava et al., 1999), and arsenic detoxification (Tu et al., 2004). It was recently shown that the processes of heavy metals hyperaccumulation and detoxification include chelation to organic acids (Stephan and Scholz, 1993; Lee et al., 1997; Oven et al., 2002) or proteins (Martens et al., 1996). Therefore, because of protection of organic acids, the sunflower biomass did not show significant differences in the three contaminated treatments.

Cadmium accumulation in plant tissues were also related to LMWOAs present in the rhizosphere soil, with both plants having similar relationships [Fig. 1(a,b)]. The correlation coefficient $(r)$ of concentrations of $\mathrm{Cd}$ in plant tissues versus LMWOAs exudates of tobacco and sunflower were 0.85 and 0.98 , respectively. The relationship between the total amounts of LMWOAs and Cd accumulation in wheat was reported by Cieśliński et al. (1998). Although mechanisms of Cd uptake and translocation within the plants are not well known, the process that have been proposed to account for $\mathrm{Cd}$ accumulation in plant tissue generally include formation of metal-organic complexes (Krotz et al., 1989; Vogeli-Lange and Wagner, 1990). Delhaize et al. (1993a,b) suggested that excretion of organic acids from the roots in the rhizosphere has been implicated in heavy metal avoidance or tolerance mechanism. Krishnamurti et al. (1997) reported that $\mathrm{Cd}$ in the soil was released from the solid phase of similar soils into soil solution through Cd-organic ligand complexation with various LMWOAs. Thus, the higher total amounts of LMWOAs found in the sunflower rhizosphere soil compared with that the tobacco suggest that these higher levels of LMWOAs were responsible for greater $\mathrm{Cd}$ availability in the rhizosphere and then accumulation of $\mathrm{Cd}$ in the plants.

\section{CONCLUSIONS}

The present study relates the amount of LMWOAs present in the rhizosphere soils to $\mathrm{Cd}$ availability for tobacco and sunflower grown in contaminated soil. In general, the tobacco and sunflower biomass was effected by $\mathrm{Cd}$ amended into soil, indicating that containing $\mathrm{Cd}$ inhibited the growth of the two plants. The sunflower, however, had accumulated higher concentration of $\mathrm{Cd}$, $\mathrm{TF}$ value, and
(A)

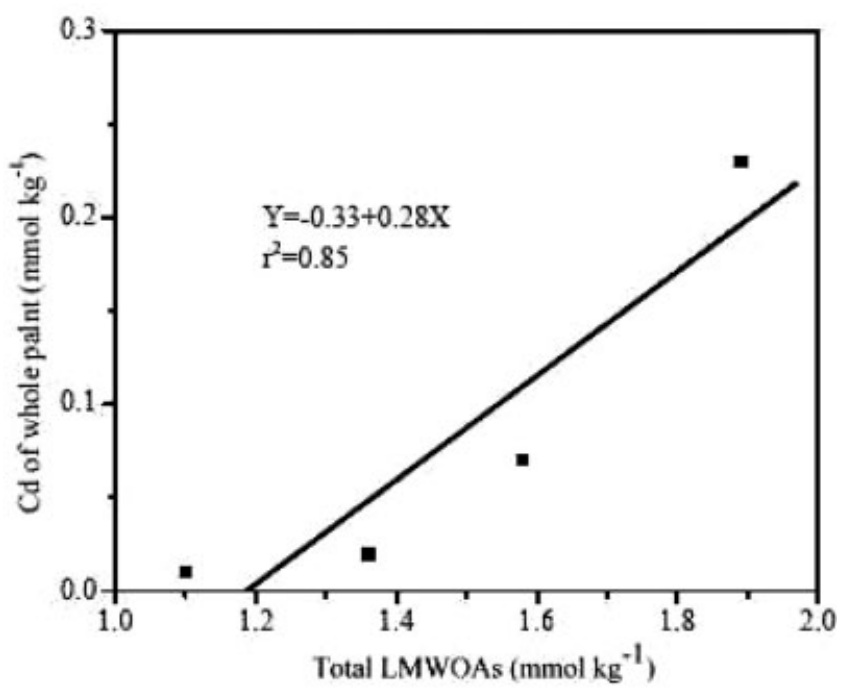

(B)

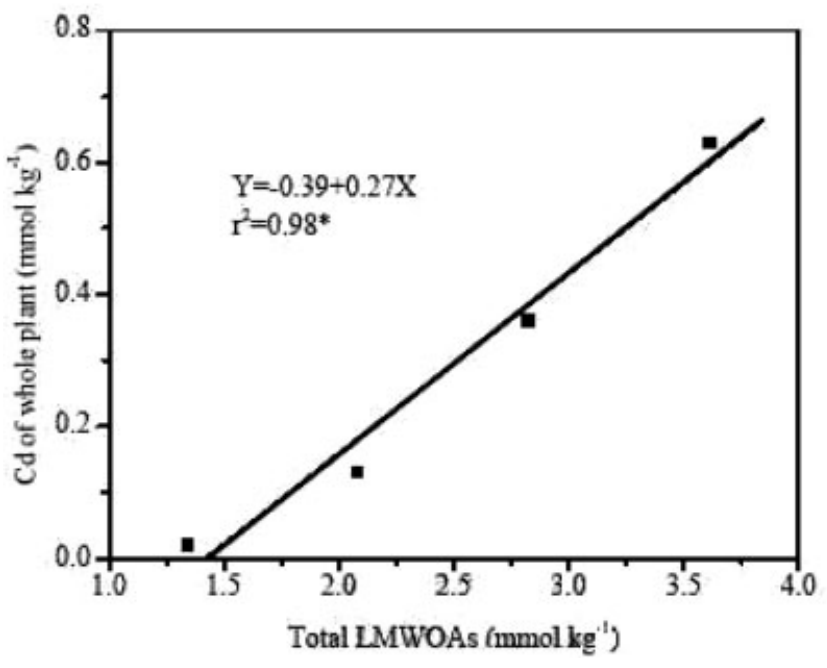

Fig. 1. Relationships between Cd contents in (A) tobacco and $(B)$ sunflower tissues, and total LMWOAs contents in rhizosphere soils.

total LMWOAs in the rhizosphere soils than that of the tobacco. The higher concentration of LMWOAs in the rhizosphere soil of the sunflower suggests that more $\mathrm{Cd}$ was released into soil solution as Cd-LMWOAs complexes, which in turn resulted in increased $\mathrm{Cd}$ uptake by the sunflower. Thus, plant roots can stimulate and exudated of LMWOAs to overcome the stress of Cd contaminants. This strategy has advantages in reducing the risk that may have been present by having plants with Cd levels in the field for long periods of time. The exudation of LMWOAs in the rhizosphere soils of sunflower and tobacco has high correlation with $\mathrm{Cd}$-amended and been implicated in $\mathrm{Cd}$ avoidance or tolerance mechanism. Moreover, the organic acids in the 
rhizosphere that was exudated by sunflower and tobacco would form strong complexes with $\mathrm{Cd}$, like $\mathrm{Cd}$-citrate, and will be undetected. Applying this technique in the field will speed up the removal of $\mathrm{Cd}$ from contaminated soils and provide a cost-effective soil decontamination strategy. Most important, this technology represents an environmentfriendly alternative for the cleanup of Cd-contaminated soils. One advantage of using the sunflower or tobacco for phytoremediation is the possibility of obtaining some economic returns during the process. For this, the total biomass and efficiency of Cd uptake for the purpose of phytoremediation must be considered. Other advantages of phytoremediation (assuming a vegetative cover sufficiently dense) include the minimization of wind and water erosion, and subsequent prevention of runoff and sediment losses loaded with particulate contaminants.

\section{REFERENCES}

Baker AJM, Brooks RR. 1989. Terrestrial higher plants which hyperaccumulate metallic elements-A review of their distribution, ecology and phytochemistry. Biorecovery 1:81-126.

Basu U, Douglas G, Taylor GJ. 1994. Aluminum resistance in Triticum aestivum associated with enhanced exudation of malate. J Plant Physiol 144:747-753.

Baziramakenga R, Simard RR, Leroux GD. 1995. Determination of organic acids in soil extracts by ion chromography. Soil Biol Biochem 27:349-356.

Cai S, Yue L, Hu ZN, Zhong XZ, Ye ZL, Xu HD. 1990. Cadmium exposure and health effects among residents in an irrigation area with ore dressing waste water. Sci Total Environ 90:67-73.

Chaney RL, Malik M, Li YM, Brown SL, Brewer EP, Angle JS, Baker AJM. 1997. Phytoremediation of soil metals. Environ Biotechnol 8:279-284.

Chen MC, Wang MK, Chiu CY, Huang PM, King HB. 2001. Determination of low molecular weight dicarboxylic acids and organic functional groups in rhizosphere and bulk soils of Tsuga and Yushiana in a temperate rain forest. Plant Soil 231:37-44.

Chiang PN, Wang MK, Wang JJ, Chiu CY. 2005. Low molecular weight organic acids exudation of rape (Brassica campestris) roots in cesium-contaminated soils. Soil Sci 170:726-733.

Cieśliński G, Van Rees KCJ, Szmigielska AM, Krishnamurti GSR, Huang PM. 1998. Low-molecular-weight organic acids in rhizosphere soils of durum wheat and their effect on cadmium bioaccumulation. Plant Soil 203:109-117.

Clemens S. 2001. Molecular mechanisms of plant tolerance and homeostasis: A review. Planta 212:457-486.

Cobbet CS. 2000. Phytochelatins and their roles in heavy metal detoxification. Plant Physiol 123:825-832.

Cristofaro AD, Zhou DH, He JZ, Violante A. 1998. Comparison between oxalate and humate on copper adsorption on goethite. Fresenius Environ Bull 7:570-576.

Cui Y, Zhu Y, Zhai R, Chen D, Huang Y, Qiu Y, Liang J. 2004. Transfer of metals from soil to vegetables in an area near a smelter in Nanning, China. Environ Int 30:785-791.
Cunningham SD, Berti WR, Huang JW. 1995. Phytoremediation of contaminated soils. Trends Biotechnol 13:393-397.

Delhaize E, Craig S, Beaton CD, Bennet RJ, Jagadish VC, Randall PJ. 1993a. Aluminum tolerance in wheat (Triticum Aestivum L.). I. Uptake and distribution of aluminum in root apices. Plant Physiol 103:685-693.

Delhaize E, Craig S, Beaton CD, Bennet RJ, Jagadish VC, Randall PJ. 1993b. Aluminum tolerance in wheat (Triticum Aestivum L.). I. Aluminum-stimulated excretion of malic acid from root apices. Plant Physiol 103:695-702.

Dushenkov V, Kumar ,PBAN, Motto H, Raskin I. 1995. Rhizofiltration: The use of plants to remove heavy metals from aqueous streams. Environ Sci Technol 29:1239-1245.

Dushenkov S, Vasudev D, Kapulnik Y, Gleba D, Fleisher D, Ting KC, Ensley B. 1997. Removal of uranium from water using terrestrial plants. Environ Sci Technol 31:3468-3474.

Ebbs SD, Kochian LV. 1998. Phytoremediation of zinc by oat (Avina sativa), barley (Hordeum vulgare) and Indian mustard (Brassica juncea). Environ Sci Technol 32:802-806.

Fox TR, Comeford NB. 1990. Low molecular weight organic acids in selected forest soils of the Southwestern USA. Soil Sci Soc Am J 54:139-114.

Garbisu C, Alkorta I. 2001. Phytoextraction: A cost-effective plant-based technology for the removal of metals from the environment. Bioresour Technol 77:229-236.

Gee GW, Bauder JW. 1986. Particle-size analysis. In: Klute A, editor. Method of Soil Analysis. Part 1. Physical and Mineralogical Method. Madison, WI: Soil Sci Soc Am. Agronomy Monograph, Vol. 9, 2nd ed. p 383-412.

Guivarch A, Hinsinger P, Staunton S. 1999. Root uptake and distribution of radiocesium from contaminated soils and the enhancement of Cs adsorption in the rhizosphere. Plant Soil 211:131-138.

Haas CN, Horowitz ND. 1986. Adsorption of cadmium to kaolinite in the presence of organic material. Water Air Soil Pollut 27:131-140.

Huang JW, Chen JJ, Berti WR, Cunningham SD. 1997. Phytoremediation of lead contaminated soils-Role of synthetic chelates in lead phytoextraction. Environ Sci Technol 31:800-805.

Jin T, Nordberg M, Frech W, Dumont X, Bernard A, Ye T. 2002. Cadmium biomonitoring and renal dysfunction among a population environmentally exposed to cadmium from smelting in China (ChinaCad). Biometals 15:397-410.

Jones DL, Darrah PR, Kochian LV. 1996. Critical evaluation of organic acid mediated iron dissolution in the rhizosphere and its potential role in root iron uptake. Plant Soil 180:57-66.

Kabata-Pendias A, Pendias H. 2000. Trace Elements in Soils and Plants, 3rd ed. Boca Raton, FL: CRC Press. p 143-157.

Keller C, Hammer D, Kayser A, Richner W, Brodbeck M, Sennhauser M. 2003. Root development and heavy metal phytoextraction efficiency: Comparison of different plant species in the field. Plant Soil 249:67-81.

Kraffczyk I, Trolldenier G, Beringer H. 1984. Soluble root exudates of maize: Influence of potassium supply and rhizosphere microorganisms. Soil Biol Biochem 16:315-322.

Krishnamurti GSR, Huang PM, Van Ress KCJ, Kozak LM, Rostad HPW. 1994. Microwave digestion for detection of total cadmium in soils. Commun Soil Sci Plant Anal 25:615-625. 
Krishnamurti GSR, Cieslinski G, Huang PM, Van Rees KCJ. 1997. Kinetics of cadmium release from soils as influenced by organic acids: Implication in cadmium availability. J Environ Qual 26:271-277.

Krishnamurti GSR, McArthur DFE, Wang MK, Huang PM. 2005. Biogeochemistry of soil acdmium and the impact on terrestrial food chain contamination. In: Huang PM, Gobran GR, editors. Biogeochemistry of Trace Elements in the Rhizosphere. Amsterdam, The Netherlands: Elsevier.

Krotz RM, Evangelou BP, Wagner GJ. 1989. Relationship between cadmium, zinc, Cd-peptide, and organic acids in tobacco suspension cells. Plant Physiol 91:780-787.

Krzyszowska AJ, Blaylock MJ, Vance GF, David MB. 1996. Ionchromatograph analysis of low molecular weight organic acids in Spodosol forest floor solutions. Soil Sci Soc Am J 60:1565-1571.

Kumar PBAN, Dushenkov V, Motto H, Raskin I. 1995. Phytoextraction: The use of plants to remove heavy metals from soils. Environ Sci Technol 29:1232-1238.

Lee J, Reeves RD, Brooks RR, Jaffre T. 1997. Isolation and identification of citrate-complex of nickel from nickel-accumulating plants. Phytochemistry 16:1503-1505.

Lombi E, Wenzel WW, Adriano DC. 1998. Soil contamination, risk reduction and remediation. Land Contam Reclam 6:183-197.

Lynch JM. 1990. Soil Rhizosphere. New York: Wiley.

Martens SN, Stephans BW, Grusak MA. 1996. Identification of an iron translocator/putative signal molecule in the phloem of higher plants. Plant Physiol. S111:302.

Mench M, Morel JL, Guckert A, Guillet B. 1988. Metal binding with root exudates of low molecular weight. J Soil Sci 39:521-527.

Mench MJ, Didier VL, Loffler M, Gomez A, Masson P. 1994. A mimicked in situ remediation study of metal contaminated soils with emphasis on cadmium and lead. J Environ Qual 23:58-63.

Merckx R, Vanginkel JH, Sinnaeve J, Cremers A. 1986. Plantinduced changes in the rhizosphere of maize and wheat. II. Complexation of cobalt, zinc and manganese in the rhizosphere of maize and wheat. Plant Soil 96:95-108.

Nordberg GF, Jin T, Kong Q, Ye T, Cai S, Wang Z. 1997. Biological monitoring of cadmium exposure and renal effects in a population group residing in a polluted area in China. Sci Total Environ 199:111-114.

Onyatta JO, Huang PM. 2003. Kinetics of cadmium release from selected tropical soils from Kenya by low-molecular-weight organic acids. Soil Sci 168:234-252.

Oven M, Grill E, Golan-Goldgirsh A, Kutchan TM, Meinhart HZ. 2002. Increase of free cysteine and citric acid in plant cells exposed to cobalt ions. Phytochemistry 60:467-474.

Pellet DM, Grunes DL, Kochian LV. 1995. Organic acid exudation as an aluminum-tolerance mechanism in maize (Zea mays L.). Planta 196:788-795.

Puls RW, Powell RM, Donald C, Eldred CJ. 1991. Effects of pH, solid/solution rate, ionic strength, and organic acids on $\mathrm{Pb}$ and Cd sorption on kaolinite. Water Air Soil Pollut 57/58:423-430.

Raskin I, Ensley BD. 2000. Phytoremediation of Toxic Metals using Plants to Clean up the Environment. New York: Wiley.

Raskin I, Smith RD, Salt DE. 1997. Phytoremediation of metals: Using plants to remove pollutants from the environment. Curr Opin Biotechnol 8:221-226.
Rauser WE. 1999. Structure and function of metal chelators produced by plants. Cell Biochem Biophys 31:19-48.

Reeves RD, Baker AJM. 2000. Metal-accumulating plants. In: Raskin I, Ensley BD, editors. Phytoremediation of Toxic Metals: Using Plant to Clean up. New York: Wiley. p 193-229.

Rhoade JK. 1982. Cation exchange capacity. In: Page AL, editor. Methods of Soil Analysis. Part 2. Chemical and Microbiological Properties. Madison, WI: Soil Sci Soc Am. Agronomy Monograph Vol. 9, 2nd ed. p 149-158.

Ryan JA, Pahren HR, Lucas JB. 1982. Controlling cadmium in the human food chain: A review and rationale based on health effects. Environ Res 28:251-302.

Ryan PR, Delhaize E, Randall PJ. 1995. Malate efflux from root apices and tolerance to aluminum are highly correlated in wheat. Aust J Plant Physiol 22:531-536.

Saber NE, Abdel-Moneim AM, Barakat SY. 1999. Role of organic acids in sunflower tolerance to heavy metals. Biol Plant 42:6573.

Salt DE, Blaylock M, Kumar NPBA, Dushenkov V, Ensley BD, Chet I, Raskin I. 1995. Phytoremediation: Anovelstrategy for the removal of toxic metals from the environment using plants. Biotechnology 13:468-474.

Sillen GL, Martell AE. 1964. Stability Consants of Metal Ion Complexes. London: The Chemistry Society.

Soil Survey Staff. 2003. Key of Soil Taxonomy, 9th ed. Washington, DC: United States Department of Agriculture and Soil Conservation Service.

Srivastava S, Prakash S, Srivastava MM. 1999. Chromium mobilization and plant availability-The impact of organic complexing ligands. Plant Soil 212:201-206.

Stephan UW, Scholz G. 1993. Nicotianamine: Mediator of transport of iron and heavy metals in the phloem? Physiol Plant 88:522-529.

Stevenson FJ. 1967. Organic acids in soil. In: McLaren AD, Peterson GH, editors. Soil Biochemistry. Marcel Dekker: New York. Vol. 1. p 119-149.

Strom L. 1997. Root exudation of organic acids: Importance to nutrient availability and the calcifuge and calcicole behavior of plants. Oikos 80:459-466.

Szmigielska AM, Van Ress CJ, Cieslinski G, Huang PM. 1997. Low molecular weight dicarboxylic acids in rhizosphere soil of durum wheat. J Agric Food Chem 44:1036-1040.

Tu S, Ma L, Luongo T. 2004. Root exudates and arsenic accumulation in arsenic hyperaccumulating Pteris vittata and nonhyperaccumulating Nephrolepis exaltata. Plant Soil 258:9-19.

Vigeli-Lange R, Wagner GJ. 1990. Subcellular localization of cadmium and cadmium-binding peptides in tobacco leaves. Plant Physiol 92:1086-1093.

Watanabe T, Zhang ZW, Qu JB, Xu GF, Wang JJ, Shimbo S. 1998. Urban-rural comparison on cadmium exposure among general populations in Shandong Province, China. Sci Total Environ 217:1-8.

Watanabe T, Zhang ZW, Qu JB, Gao WP, Jian ZK, Shimbo S. 2000. Background lead and cadmium exposure of adult women in Xian City and two farming villages in Shaanxi Province, China. Sci Total Environ 247:1-13. 
Wenzl WW, Lombi E, Adriano DC. 1999. Biogeochemical processes in the rhizosphere: Role in phytoremediation of metalpolluted soils. In: Prasad MNV, Hagemeyer J, editors. Heavy Metal Stress in Plants. New York: Springer. p 273-303.

Xia HP. 2004. Ecological rehabilitation and phytoremediation with four grasses in oil shale mined land. Chemosphere 54: 345-353.

Xia HP, Shu WS. 2001. Resistance to and uptake of heavy metals by Vetiveria zizanioides and Pasalum notatum from lead/zinc mine tailings. Acta Ecol Sin 21:1121-1129 (in Chinese).

Xia HP, Wang QL, Kong GH. 1999. Phyto-toxity of garbage leachates and effectivencess of plant purification for them. Acta Phytoecol Sin 23:289-301.
Yang XE, Bligar VC, Foster JC, Martens DC. 1997. Accumulation and transport of nickel in relation to organic acids in ryegrass and maize grown with different nikel levels. Plant Soil 196:271-276.

Zhang FS, Ma J, Cao JP. 1997. Phosphorus deficiency enhances root exudation of low molecular weight organic acids and utilization of sparingly soluble inorganic phosphorus by radish (Raghanus sativus L.) and rape (Brasssica napus L.) plants. Plant Soil 190:261-264.

Zhu YG, Shaw G. 2000. Soil contamination with radionuclides and potential remediation. Chemosphere 41:121128. 